$10-1-2020$

\title{
Assessing community capacity strengthening to sustain integrated social behavior change programming in northwestern Nigeria
}

Breakthrough RESEARCH

Follow this and additional works at: https://knowledgecommons.popcouncil.org/departments_sbsr-rh

Part of the Health Communication Commons, and the Public Health Commons How does access to this work benefit you? Let us know!

\section{Recommended Citation}

Breakthrough RESEARCH. 2020. "Assessing community capacity strengthening to sustain integrated social behavior change programming in northwestern Nigeria," Activity Brief. Abuja and Washington, DC: Population Council. 


\section{Assessing Community Capacity Strengthening to Sustain Integrated Social Behavior Change Programming in Northwestern Nigeria}

Breakthrough RESEARCH is conducting qualitative research to understand and evaluate efforts to prepare communities, through a community capacity strengthening (CCS) approach, to sustain community social and behavior change (SBC) programming to promote healthy family behaviors in northwestern Nigeria. This CSS approach, implemented by Breakthrough ACTION Nigeria, focuses on engaging local leaders and community organizations-namely Ward Development Committees (WDC)-to increase community agency to coordinate the local health ecosystem to strengthen health service delivery, and promote positive social norms and individual behaviors for improved health outcomes.

Specifically, Breakthrough ACTION Nigeria is implementing an intensive community SBC approach by engaging individuals in interpersonal and group dialogue at the community level. The community SBC approach targets behaviors and psychosocial influences on decision-making across multiple health areas including maternal, newborn and child health plus nutrition $(\mathrm{MNCH}+\mathrm{N})$, malaria, and family planning (FP), while also addressing social and gender norms. The CCS approach will assist WDCs in reducing structural barriers to accessing healthcare and improving health and social outcomes among their constituents. As such, Breakthrough ACTION Nigeria will additionally support WDCs to plan, implement, maintain and monitor specific SBC activities in the areas of $\mathrm{MNCH}+\mathrm{N}$, malaria, and FP.

The CCS approach has three specific objectives: (1) help communities to identify priority health areas, services and behaviors for improvement, and to demand quality health services for their priorities; (2) empower communities to mobilize resources, enhance participation in health services, and address underlying barriers to improved health, including gen- der biases and norms; and (3) increase community ownership and sustainability by developing systems to ensure continued community involvement and participation. Breakthrough RESEARCH Nigeria will assess, through a phased approach, the successes and challenges of the CCS approach in increasing community self-efficacy, cohesion and sense of ownership to support community SBC programming (phase 1); as well as the CCS approach's impact on sustained capacity and adoption of evidence based community level SBC approaches across priority health areas (phase 2).

\section{HOW WILL THIS ACTIVITY HELP IMPROVE SBC PROGRAMMING?}

Breakthrough RESEARCH's qualitative research engaging stakeholders and beneficiaries will identify potential facilitators and barriers to community capacity strengthening for sustainability in the context of Breakthrough ACTION's integrated SBC programming. This study will assess the role of the CCS in increasing communities' readiness to promote, support

\section{ACTIVITY SNAPSHOT}

Assessing community capacity strengthening to sustain integrated social behavior change programming in Nigeria

\section{BREAKTHROUGH RESEARCH CONSORTIUM}

Population Council (lead), Tulane University, Avenir Health, ideas42, Population Reference Bureau, Institute for

Reproductive Health at Georgetown University

Lead Research Partners

Tulane University, Population Council

\section{Collaborating Partners}

Breakthrough ACTION Nigeria

Anticipated Timeline

September 2020 - June 2022

Geographic Location

Bauchi and Sokoto States

Contact

Dele Abegunde (dabegunde@popcouncil.org) 
and adopt health-related behaviors and social and gender normative change in the areas of family planning, $\mathrm{MNCH}+\mathrm{N}$, and malaria. Breakthrough ACTION will use these findings for continuous learning and adaptation of their CCS programming, and results will actively inform the second stage of CCS programming in Nigeria.

The research will also provide insights regarding the functioning of WDCs and their capacity strengthening journey to inform the design of other sustainability programs at community-level as they adapt and expand. The Government of Nigeria, United States Agency for International Development (USAID), and other development partners can use the results to decide about how best to invest in sustaining community SBC approaches. The results of this research will also be disseminated to implementing partners, government officials, policy makers, and other researchers in order to contribute to the evidence-base on how CCS approaches can lead to strengthened community leadership structures for sustained SBC programming.

\section{HOW WILL THIS ACTIVITY BE IMPLEMENTED?}

Breakthrough RESEARCH will conduct qualitative research in two northern Nigerian states, Bauchi and Sokoto, where integrated SBC programming is being implemented and the CCS approach is being deployed. We will conduct in-depth interviews with program stakeholders and focus groups with project beneficiaries, stratifying wards by level of early success in their path to community-owned programming through the CCS approach. This research includes:

- In-depth interviews with members of WDCs, village development committees, community volunteers, Breakthrough ACTION program staff, and local government officials. These

\section{ANTICIPATED PRODUCTS AND ENGAGEMENTS}

Qualitative phase one and phase two datasets

Research report and scientific articles

User-friendly briefs

Targeted workshops, meetings, and/or webinars for

local and global SBC policymakers and practitioners

interviews will explore communities' definition of effective community leadership and capacity, perceived facilitators and barriers to sustainability by health area, and gender and social norms.

- Focus group discussions with beneficiaries will include discussions among women $18-24$ and $25-49$ years of age, and men $18-24$ and $25-49$ years of age. These discussions will explore the beneficiaries' experiences, satisfaction withand effectiveness of-the community SBC programming, as well as their perceptions of the community leadership structures.

\section{TIMELINE}

The research will be implemented in two phases. The first phase of the research will explore early successes and challenges of the CCS approach in communities' transition to self-reliance and community ownership. The results of the first phase will inform Breakthrough ACTION's implementation and the development of the second phase, which will assess the CCS approach's potential for longer-term sustainability of community-led activities, their impact and normative transformations across $\mathrm{MNCH}+\mathrm{N}$, malaria and family planning.

\begin{tabular}{|c|c|c|c|}
\hline PHASE 1 & ANALYSIS & PHASE 2 & ANALYSIS \\
\hline $\begin{array}{l}\text { Explore early successes and } \\
\text { challenges of the CCS } \\
\text { approach }\end{array}$ & $\begin{array}{c}\text { Programmatic } \\
\text { recommendations for } \\
\text { Breakthrough ACTION Nigeria } \\
\text { implementation }\end{array}$ & $\begin{array}{l}\text { Assess how implementation of } \\
\text { CCS impacts community SBC } \\
\text { activities across health areas }\end{array}$ & $\begin{array}{l}\text { Document the impact of CCS on readiness } \\
\text { and potential for longer term sustainability of } \\
\text { community-led SBC activities across priority } \\
\text { health areas of } \mathrm{FP}, \mathrm{MNCH}+\mathrm{N} \text {, and malaria }\end{array}$ \\
\hline & $\begin{array}{l}\text { Inform the development of } \\
\text { research and tools for phase II }\end{array}$ & & $\begin{array}{l}\text { Provide evidence of the value of CCS } \\
\text { for sustainability of SBC programs } \\
\text { across health areas }\end{array}$ \\
\hline
\end{tabular}

\section{Breakthrough RESEARCH}

This activity is being implemented as part of Breakthrough RESEARCH. Breakthrough RESEARCH catalyzes social and behavior change (SBC) by conducting state-of-the-art research and evaluation and promoting evidence-based solutions to improve health and development programs around the world. Breakthrough RESEARCH is a consortium led by the Population Council in partnership with Avenir Health, ideas42, Institute for Reproductive Health at Georgetown University, Population Reference Bureau, and Tulane University.

\section{Acknowledgements}

Breakthrough RESEARCH is made possible by the generous support of the American people through the United States Agency for International Development (USAID) under the terms of cooperative agreement no. AID-OAA-A-17-00018. The contents of this document are the sole responsibility of Breakthrough RESEARCH and Population Council and do not necessarily reflect the views of USAID or the United States Government.

\section{Breakthrough RESEARCH}

Plot 839 Idris Ibrahim Crescent

Jabi, Abuja, Nigeria

+2348067787750

Population Council

4301 Connecticut Avenue, NW | Suite 280

Washington, DC 20008

Tel: +1 2022379400

breakthroughactionandresearch.org

\section{Photo Credit}

OKC NWAKALOR FOR USAID/DIGITAL DEVELOPMENT COMMUNICATIONS 